\title{
動眼神経麻痺を発症した硬膜内脳動脈瘤に 対する瘤内塞栓術
}

\author{
荻野達也 ${ }^{1)}$ 漂子敏夫 ${ }^{1)}$ 片岡丈人 ${ }^{1 ｝ \text { 早瀬一幸 }{ }^{1)} \text { 遠藤英樹 }{ }^{1)} \text { 中村博彦 }{ }^{1)}$
}

\section{Endosaccular coil embolization for intradural aneurysms presenting oculomotor nerve palsy}

\author{
Tatsuya OGINO ${ }^{1)}$ Toshio HYOGO ${ }^{1)}$ Taketo KATAOKA ${ }^{1)}$ Kazuyuki HAYASE $^{1)}$ \\ Hideki ENDO $^{1)}$ Hirohiko NAKAMURA ${ }^{1)}$
}

1) Department of Neurosurgery, Nakamura Memorial Hospital

\begin{abstract}
O
Purpose: To review the clinical outcome of endosaccular coil embolization for intradural aneurysms presenting oculomotor nerve palsy. Materials and Methods: We treated 6 cases of intradural aneurysms presenting oculomotor nerve palsy. There were 4 cases of subarachnoid hemorrhage and 2 cases of non-ruptured aneurysms. The aneurysms were located at 4 internal carotid-posterior communicating artery (IC-PC) in 4 cases, internal carotid-anterior choroidal artery (IC-AchoA) in another and at basilar artery-superior cerebellar artery (BA-SCA) in the other. The size of the aneurysms ranged from 5.8 to $8.7 \mathrm{~mm}$. Four cases presented complete oculomotor nerve palsy, and 2 cases incomplete.

Results: Complete recovery from oculomotor nerve palsy was achieved in 4 cases and partial recovery in 2 cases. Two cases with pre-operative incomplete oculomotor nerve palsy recovered completely. To facilitate recovery from oculomotor nerve palsy, loose packing of the aneurysmal bleb was intentionally performed in selected cases.

Conclusion: In spite of persistent anatomical contact or close proximity of the aneurysm to the oculomotor nerve, endosaccular coil embolization is an effective treatment in comparison to surgical clipping. The presence of the pre-operative oculomotor nerve palsy does not influence the selection of the clipping or coiling treatment methods.
\end{abstract}

Key Words

coil embolization, intradural aneurysm, oculomotor nerve palsy

1) 中村記念病院 脳神経外科

(Received February 27, 2009 : Accepted July 14, 2009)

<連絡先：荻野達也 $\bar{T} 060-8570$ 札幌市中央区南 1 条西14丁目 E-mail：ogino@med.nmh.or.jp>

\section{緒 言}

動眼神経麻痺は, 内澒動脈一後交通動脈分岐部 (internal carotid-posterior communicating artery (IC-PC) aneurysm）や内頝動脈一前脈絡叢動脈分岐部動脈瘤 (internal carotid-anterior choroidal (IC-AchoA) artery) の臨床症状として広く知られており，稀には脳底動脈一 上小脳動脈分岐部 (basilar artery-superior cerebellar artery（BA-SCA） aneurysm） や脳底動脈一後大脳動脈 分岐部の硬膜内脳動脈瘤でも認められる ${ }^{5,8)}$.

これらの硬膜内脳動脈瘤による動眼神経麻痺の発症 は，くも膜下出血（SAH）を伴う場合と，くも膜下出 血の警告症状として発症する場合がある。すべてのくも
膜下出血で認められる症状ではないので, 脳動脈瘤と動 眼神経の解剖学的位置関係は, 非常に近接していて出血 の影響で発症する場合と，脳動脈瘤と動眼神経そのもの が接触していて脈波の伝達で発症する状況が想定され る. いずれの場合もこの状況におけるコイル塞栓術は, 神経と動脈瘤との解剖学的位置関係を保ったままでの治 療となるため, 圧の伝達の観点からは術後の動眼神経麻 痺の回復に関して不利となる可能性が考えられてきた. 我々は 6 例の動眼神経麻痺で発症した硬膜内脳動脈瘤に 対してコイル塞栓術を施行し, 術後の動眼神経麻痺の回 復経過について文献的考察を加え報告する。 
Table 1 Case summary of 6 cases presenting oculomotor nerve palsy

\begin{tabular}{c|c|c|c|c|c|c|c}
\hline Case no. & $\begin{array}{c}\text { Age/ } \\
\text { Gender }\end{array}$ & Location & Size $(\mathrm{mm})$ & $\begin{array}{c}\text { SAH/ } \\
\text { non-SAH }\end{array}$ & $\begin{array}{c}\text { Oculomotor } \\
\text { nerve palsy }\end{array}$ & $\begin{array}{c}\text { From the onset } \\
\text { to treatment (days) }\end{array}$ & Recovery \\
\hline 1 & $51 / \mathrm{F}$ & IC-AchoA & $7.6 \times 3.0$ & SAH & complete & 0 & full (5 Mo) \\
2 & $59 / \mathrm{F}$ & IC-PC & $8.0 \times 7.8$ & SAH & complete & 0 & incomplete $(6 \mathrm{Mo})$ \\
3 & $42 / \mathrm{F}$ & IC-PC & $5.8 \times 3.8$ & non-SAH & partial & 3 & full (1 Mo) \\
4 & $66 / \mathrm{F}$ & IC-PC & $5.8 \times 4.1$ & SAH & partial & 1 & full (5 Mo) \\
5 & $55 / \mathrm{M}$ & BA-SCA & $8.7 \times 5.7$ & SAH & complete & 1 & full (8 Mo) \\
6 & $72 / \mathrm{M}$ & IC-PC & $7.9 \times 4.4$ & non-SAH & complete & 20 & incomplete $(5 \mathrm{Mo})$ \\
\hline
\end{tabular}

BA-SCA : basilar artery-superior cerebellar artery, F : female, IC-AchoA : internal carotid-anterior choroidal artery, IC-PC : internal carotid-posterior communicating artery, M : male, Mo : months, SAH : subarachnoid hemorrhage.

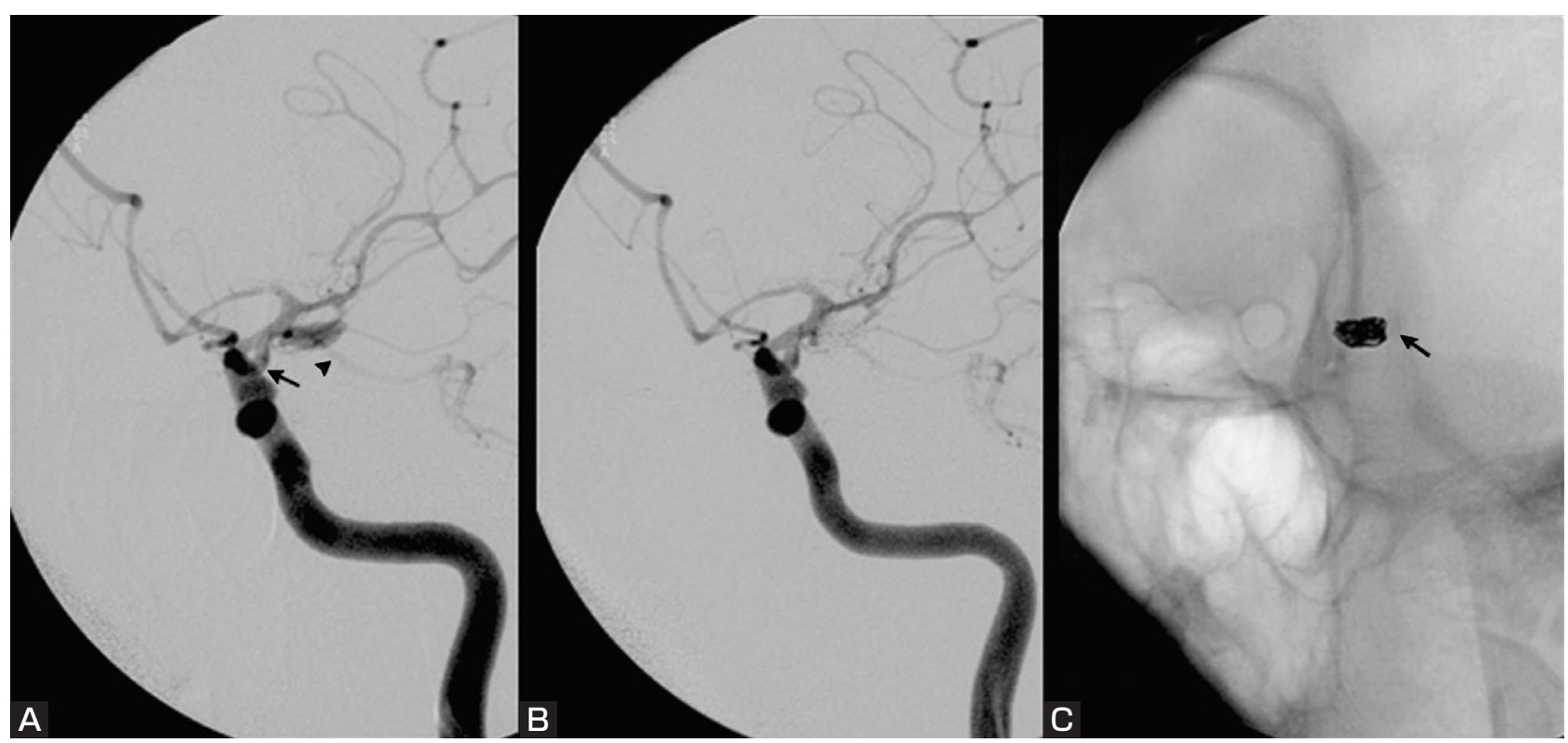

Fig. 1 A 51-year-old female with a ruptured left internal carotid-anterior choroidal artery (IC-AchoA) aneurysm with ICA fenestration. A : Pre-treatment left internal carotid angiography (oblique view) demonstrates ICA fenestration (arrow), diffuse vasospasm and ICA aneurysm $(7.6 \times 3.0 \mathrm{~mm})$. The aneurysm is located at the origin of the anterior choroidal artery (arrowhead). The posterior cerebral artery is branched off from the anterior choroidal artery.

B : Post-embolization angiography showing almost complete occlusion of the aneurysm.

C : Arrow indicates a blank of coil at the aneurysmal tip.

\section{対象と方法}

対象は1999年10月から2008年 5 月までにコイル塞栓術 を施行した動眼神経麻痺で発症した硬膜内脳動脈瘤 6 例 である. 症例の一覧をTable 1に示す．男性 2 例，女性 4 例で, 平均年齢57.5歳であった。部位は内頝動脈一後 交通動脈分岐部（IC-PC） 4 例，内頝動脈一前脈絡叢 動脈分岐部 (IC-AchoA) 1 例, 脳底動脈一上小脳動脈分 岐部（BA-SCA） 1 例で，最大径5.8～8.7 mmであった. くも膜下出血は 4 例，未破裂脳動脈瘤は 2 例であり，動 眼神経麻痺の程度は完全麻痺 4 例，不全麻痺 2 例であっ
た．塞栓術は本来の目的である再出血の防止を第一に考 えて行い, 脳動脈瘤の先端にblebが認められた場合には, blebにより動眼神経麻痺をきたしている可能性も考えら れるため, bleb内へのコイルの挿入をできる限り避け, dome内での塞栓術をするよう努めた.

\section{症例呈示}

症例 1：51歳女性. Hunt \& Kosnik (H\&K) grade III の SAH再発にて発症した. 内䅡動脈のfenestrationを伴う IC-AchoAの部位に最大径7.6 mmの先端にblebを伴う縦 長の脳動脈瘤を認めた (Fig. 1). 後交通動脈は造影さ 


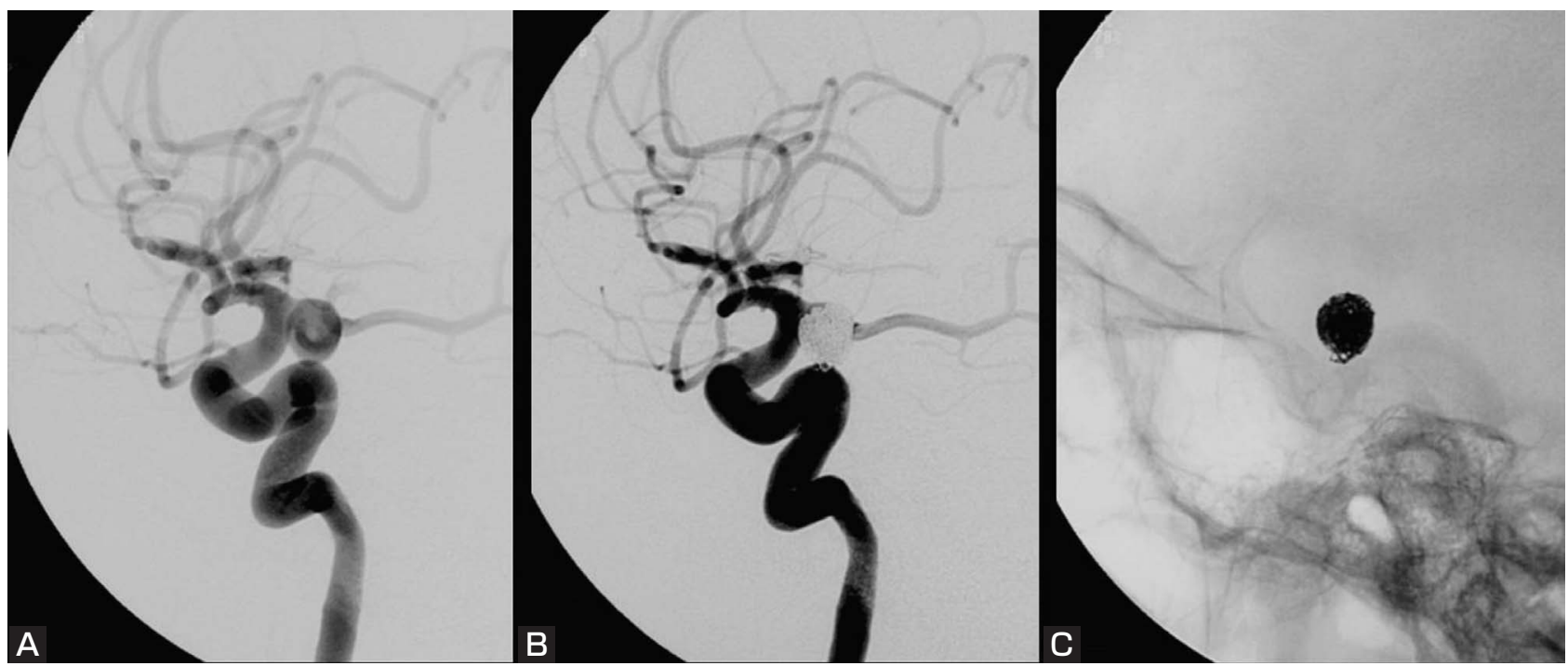

Fig. 2 A 59-year-old female with a ruptured left internal carotid-posterior communicating artery (IC-PC) aneurysm.

A : Pre-treatment left internal carotid angiography (lateral oblique view) demonstrating IC-PC aneurysm $(8.0 \times 7.8 \mathrm{~mm})$.

B : Post-embolization angiography shows complete occlusion of the aneurysm.

C : Dense coil packing in the aneurysm.

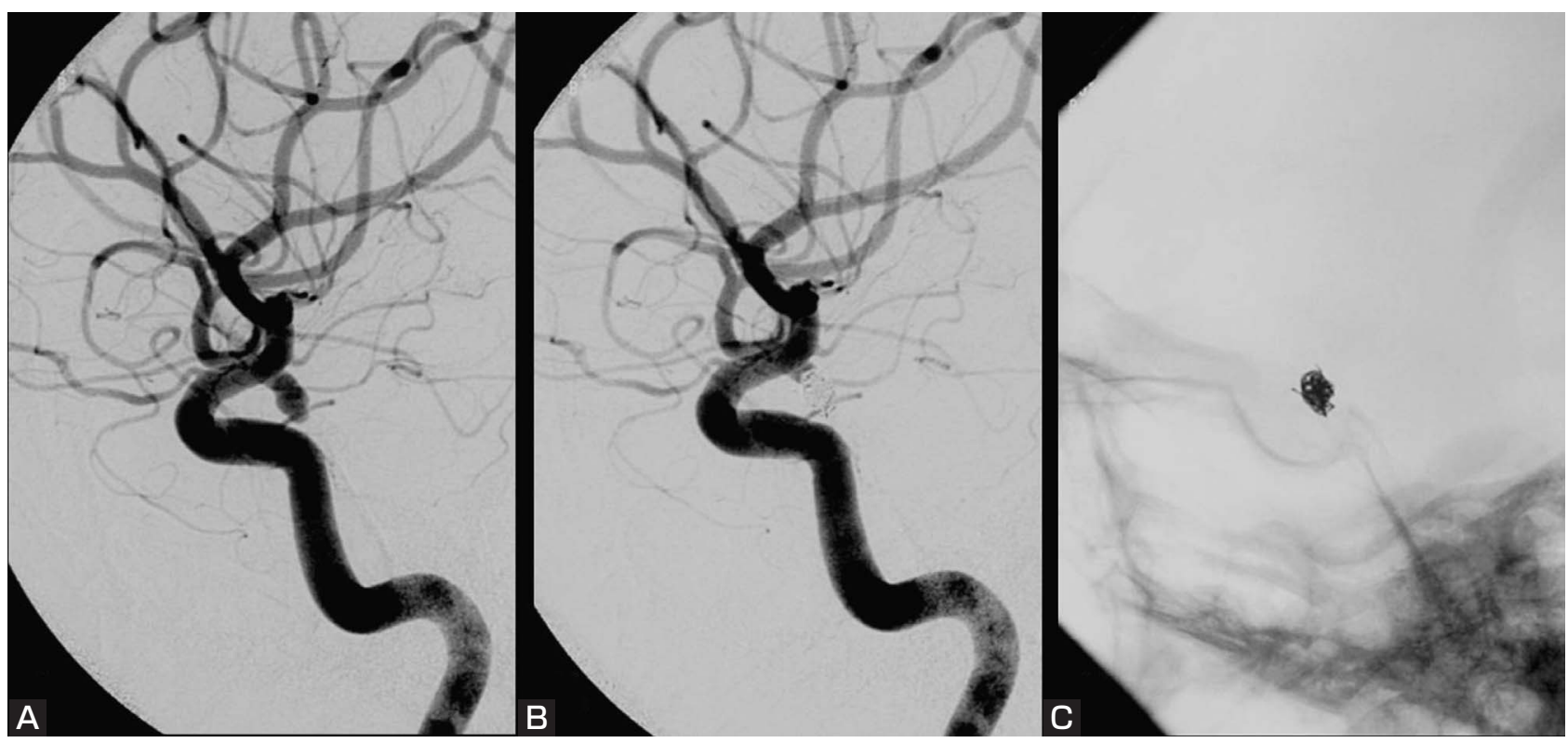

Fig. 3 A 42-year-old female with a non-ruptured right internal carotid-posterior communicating artery (IC-PC) aneurysm.

A : Pre-treatment internal carotid angiography (lateral oblique view) demonstrating IC-PC aneurysm $(5.8 \times 3.8 \mathrm{~mm})$.

B : Post-embolization angiography demonstrating sufficient aneurysm occlusion with some neck remnant.

C : Intentional loose coil packing in the aneurysmal bleb and neck to preserve the posterior communicating artery.

れず，一部後大脳動脈の枝は前脈絡叢動脈から分岐して いた．術中，先端部のblebにコイルを挿入しないように 工夫して塞栓した. 術前は完全動眼神経麻痺であったが, 5 カ月後には完全回復した.

症例2：59歳女性. H\&K grade III のSAHにて発症した. 完全動眼神経麻痻を呈していた。IC-PCに最大径 $8.0 \mathrm{~mm}$ の脳動脈瘤を認めた（Fig. 2)。脳動脈瘤を全体にtight packingし完全閉塞が得られた。術後 6 力月の時点では 眼瞼下垂は改善したものの，瞳孔散大による差明と軽度 の上下転障害が残存している。

症例3：42歳女性. 眼瞼下垂と瞳孔不同で発症した。 IC-PCに最大径 $5.8 \mathrm{~mm}$ の未破裂脳動脈瘤を認めた（Fig. 3)。動眼神経麻痺は，塞栓術後 8 日目に瞳孔不同が消 失し，1 月月後には完全回復が得られた. 


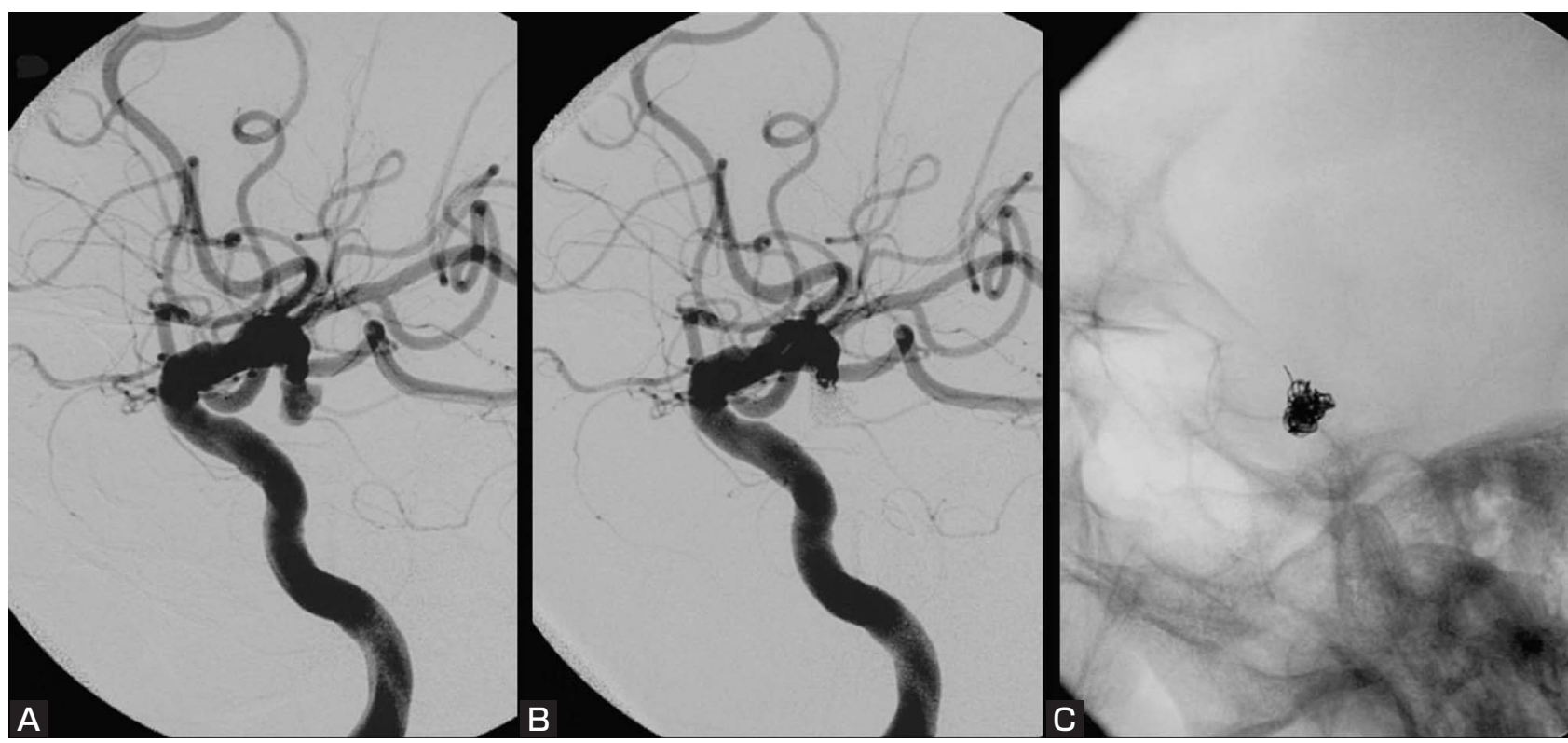

Fig. 4 A 66-year-old female with a ruptured right internal carotid-posterior communicating artery (IC-PC) aneurysm.

A : Pre-treatment internal carotid angiography (lateral oblique view) demonstrating irregular shape of IC-PC aneurysm $(5.8 \times 4.1 \mathrm{~mm})$.

B : Post-embolization angiography demonstrating sufficient occlusion of the aneurysm with preserving the posterior communicating artery.

C : Intentional loose coil packing in the aneurysmal bleb and protrusion of the coil at the neck are noted.

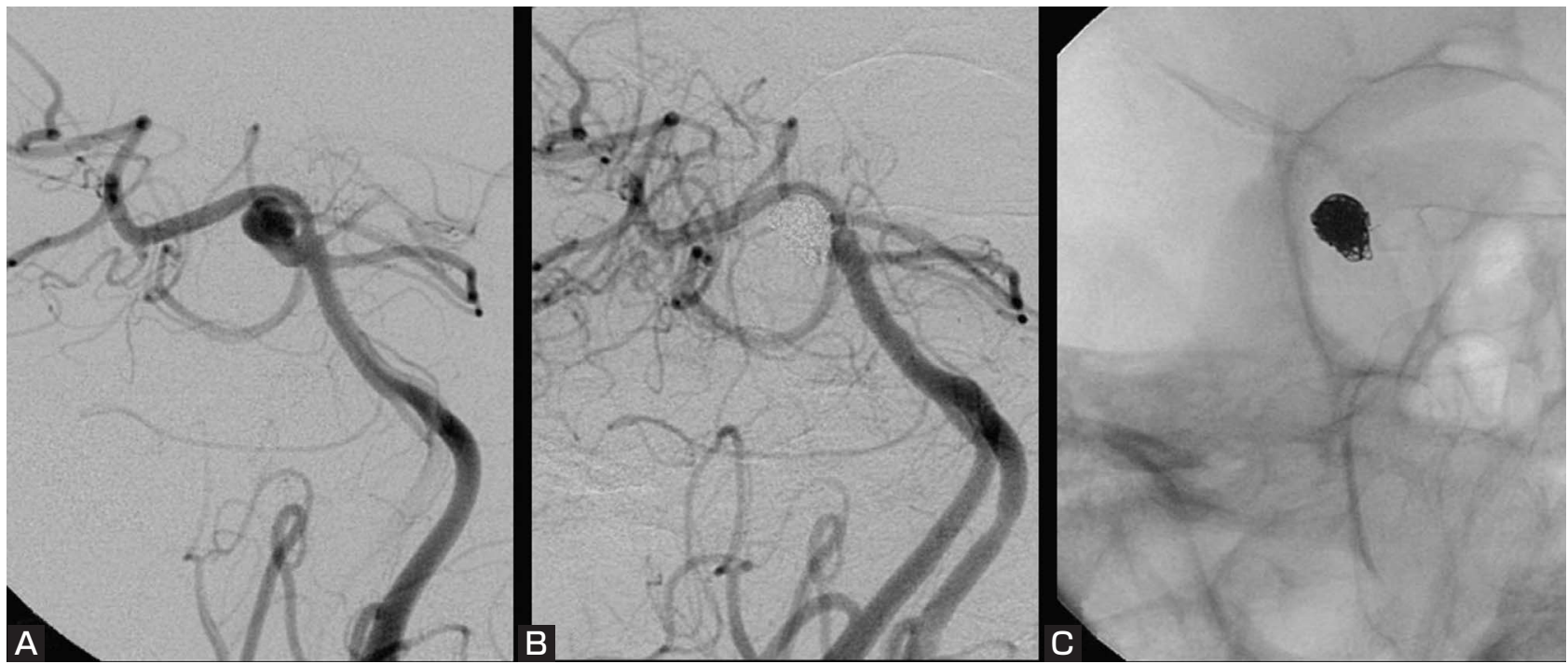

Fig. 5 A 55-year-old male with a ruptured right basilar artery superior cerebellar artery (BA-SCA) aneurysm.

A : Pre-treatment vertebral angiography (oblique view) showing BA-SCA aneurysm $(8.7 \times 5.7 \mathrm{~mm})$.

B : Post-embolization angiography showing complete occlusion of the aneurysm.

C : Tight packing of the aneurysm is noted.

症例 4：66歳女性. 眼瞼下垂を伴うH\&K grade I のSAH にて発症した。 IC-PCに最大径 $5.8 \mathrm{~mm}$ の脳動脈瘤を認め た (Fig. 4). 術直後，上転障害の一過性の悪化を認め たが，その後改善し，5力月目には完全に回復した。

症例 $5:$ 55歳男性. H\&K grade III のSAHで発症した. BA-SCAに最大径8.7 mmの脳動脈瘤を認めた（Fig. 5). 完全動眼神経麻痺を呈していたが，術後 5 カ月の時点で
眼球運動は完全回復し，術後 8 力月では対光反射も正常 化して完全回復した.

症例 6 : 72歳男性. 複視で発症し，治療までに20日間が 経過していた。術前は完全動眼神経麻痺であった。IC$\mathrm{PC}$ に最大径 $7.9 \mathrm{~mm}$ の未破裂脳動脈瘤を認め，先端部分 をlooseに塞栓した (Fig. 6)。術後 5 力月の時点では眼 球運動の改善傾向は認められるものの，動眼神経麻痺は 


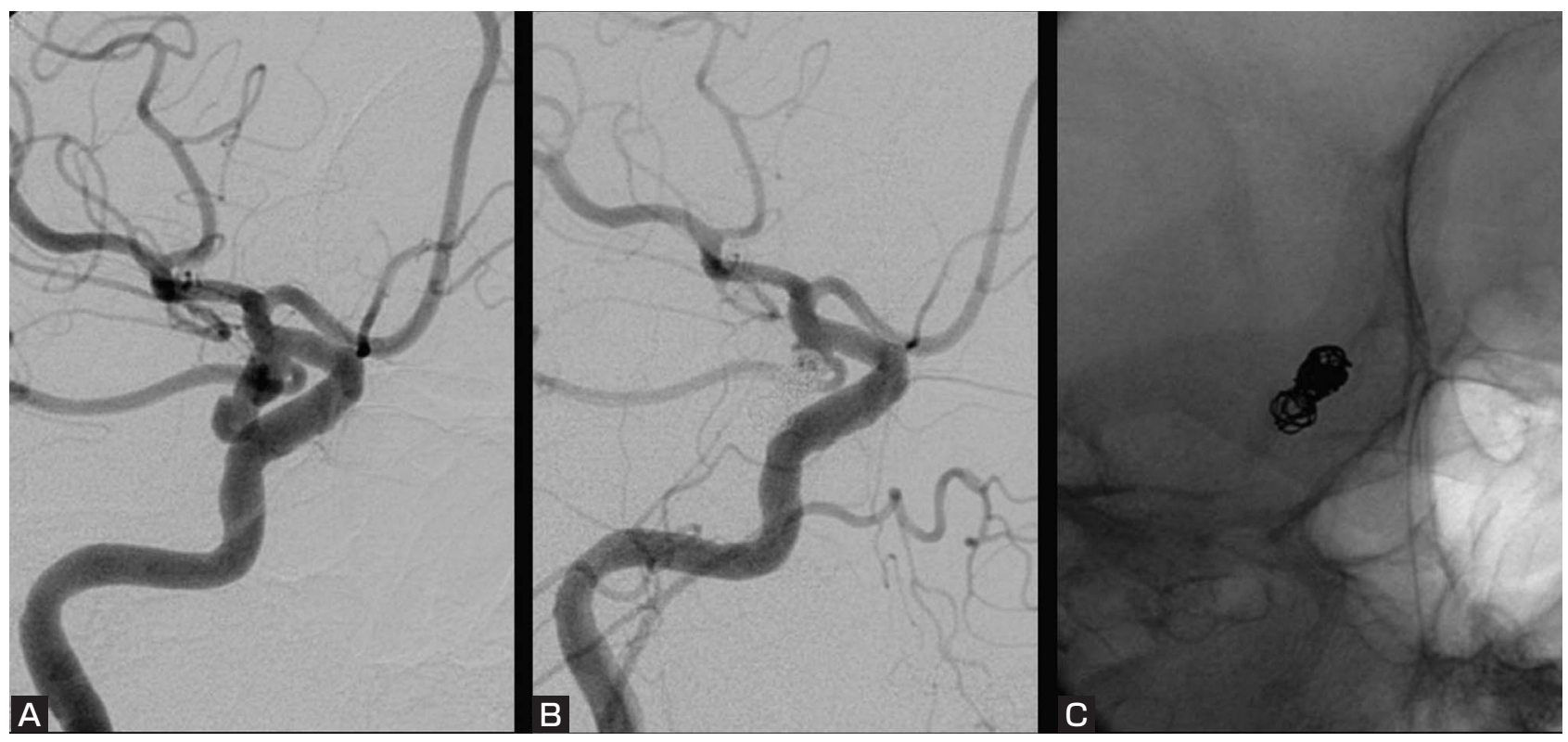

Fig. 6 A 72-year-old male with a non-ruptured right internal carotid-posterior communicating artery (IC-PC) aneurysm.

A : Pre-treatment internal carotid angiography (oblique view) demonstrating a dumbbell shaped IC-PC aneurysm $(7.9 \times 4.4 \mathrm{~mm})$.

B : Post-embolization angiography showing remnant neck of the aneurysm.

C : Intentional loose packing in the distal dome of the aneurysm is noted.

不完全回復となっている.

\section{結 果}

動眼神経麻痺の改善は全例で認められ，完全回復が 4 例，不完全回復が 2 例であった（Table 1)，不完全回復 の 2 例ではいずれも瞳孔散大が残存し, 眼球運動障害は 1 例でほぼ完全回復して自覚症状は差明のみであるが, 他の 1 例では複視も残存している. 不完全回復の 2 例の うち，1例はIC-PCの中で最もサイズが大きい症例で あり， 1 例は年齢が最も高く, 発症から治療までの期間 が長い症例であった，術前の神経麻痺の重症度との関係 は，完全麻痺であった 4 例のうち 2 例が完全回復し，不 全麻痺であった 2 例は，いずれも完全回復が得られた。

\section{考察}

脳動脈瘤の症状として動眼神経麻痺が起こる機序に は，拍動する動脈瘤のmass effect打よびその破裂5)，癒 着した脳動脈瘤に伴う irritation ${ }^{6)}$ ，などが考えられてい る.

脳動脈瘤に対するコイル瘤内塞栓術では，動脈瘤の形 態は術後も残存し, 動眼神経との解剖学的関係, 近接性 も基本的には不変である。したがって動眼神経麻痺の術 後の回復に関し瘤内塞栓術は, 近接性の保持が回復の妨 げとなり，動脈瘤と神経との癒着・接触を解除し得るク
リッピング術と比べ不利となる可能性がある，とされて きた。一方，クリッピング術では，神経との剥離操作に よる侵襲が回復を遅延させる可能性がある。

動眼神経麻痺にて発症したIC-PCの脳動脈瘤に対す るコイル塞栓術に関して, Birchallらが 3 例2), Mavilio らが 6 例8) の報告をしている. いずれも，脳動脈瘤の大 きさやSAHの状況にかかわらず，コイル塞栓術後の良 好な動眼神経麻痺の回復を報告している。一方で, Stiebel-Kalishらは術前が完全動眼神経麻痺の症例11例 において，10例に改善が認められたものの，いずれも完 全回復には至らなかったと報告している9 . また, Ahn らはほぼ同数のコイル塞栓術後とクリッピング術後の経 過を報告し, 両者の間で改善度に差は無かったと述べて いる ${ }^{1)}$.また，回復を左右する因子として，脳動脈㽣の サイズは有意差を認めず, 術前の神経麻瘏の程度と糖尿 病合併の有無，および年齢に統計的有意差を認めたとし ている. 一方Chenらは, 同様にコイル塞栓術とクリッ ピング術を比較して, クリッピング術後の完全回復率が 高かったとし，クリッピング術を推奨している4). クリ ッピング術後の改善度に関しては，Yanakaらの報告の 中で未破裂脳動脈瘤の術後14例のうち, 完全回復 7 例, 不完全回復 6 例, 不変 1 例で, 動眼神経麻痺の発症から 治療までの期間が改善度を左右するとしている ${ }^{10)}$. Bulsaraらは過去の論文レビューをして，コイル塞栓術 
は $65 \%$ が改善し，そのうち $71 \%$ が完全回復，クリッピン グ術は $93 \%$ が改善し，そのうち $43 \%$ が完全回復とし，コ イル塞栓術では完全回復率が高く，クリッピング術では 改善率が高いと報告している3).

回復に影響を与える因子として，動脈瘤の大きさが特 に回復の妨げになるとの報告は認められず，年齢，糖尿 病合併の有無，治療までの期間，術前の動眼神経麻痺の 程度などが予後を左右するとした報告が多い, ${ }^{1,4,7,9,10)}$ 。今 回の自験例においても不完全回復例には，術前の完全動 眼神経麻痺，高歯，治療の遅れといった要因があり，こ れらが回復の妨げとなった可能性が考えられた。

コイル塞栓術は動脈瘤と動眼神経との解剖学的関係を 保ったままの治療となるが，術後の拍動の減弱が神経機 能の回復をもたらすと考えられ ${ }^{1,2,7,9)}$ ，また，クリッピン グ術と比べて動眼神経へはatraumaticであることが，良 好な回復経過に関係していると考察された ${ }^{2,7)}$. 動眼神 経と接している可能性のあるblebが認められる場合に は，bleb内へのコイルの挿入をできる限り避け， dome 内でのtight packingを行い血管造影上のblebの消失を困 るような塞栓術を行うことにより，神経と接する部位に おける治療の影響を少なくし得ると考えられる。

\section{結 語}

動眼神経麻痺を呈した硬膜内脳動脈瘤に対するコイル 塞栓術を 6 例に対して施行し, 術後回復経過を報告した. 術前が完全麻痺であった 4 例のうち 2 例では不完全回復 であったが，そのほかはいずれも完全回復が得られた。 過去の報告では，コイル塞栓術後の動眼神経麻痺の回復 は必ずしも不良ではなく，神経と動脈瘤との解剖学的関 係を保ったままでの治療であっても，術後の回復経過に 影響を与えないと思われた。したがって現状では，動眼 神経麻痺の有無は，脳動脈瘤の治療方法の選択に影響を 与えないと考えられる。

\section{文 献}

1) Ahn JY, Han IB, Yoon PH, et al: Clipping vs coiling of posterior communicating artery aneurysms with third nerve palsy. Neurology 66:121-123, 2006.

2 ) Birchall D, Khangure MS, McAuliffe W: Resolution of third nerve paresis after endovascular management of aneurysms of the posterior communicating artery. AJNR 20:411-413, 1999.

3 ) Bulsara KR, Jackson D, Galvan GM: Rate of third nerve palsy recovery following endovascular management of cerebral aneurysms. Neurosurg Rev 30:307-311, 2007.

4 ) Chen PR, Amin-Hanjani S, Albuquerque FC, et al: Outcome of oculomotor nerve palsy from posterior communicating artery aneurysms: comparison of clipping and coiling. Neurosurgery 58:1040-1046, 2006.

5 ) Giombini S, Ferraresi S, Pluchino F: Reversal of oculomotor disorders after intracranial aneurysm surgery. Acta Neurochir (Wien) 112:19-24, 1991.

6 ) Lanzino G, Andreoli A, Tognetti F, et al: Orbital pain and unruptured carotid-posterior communicating artery aneurysms: the role of sensory fibers of the third cranial nerve. Acta Neurochir(Wien) 120:7-11, 1993.

7 ) Mansour N, Kamel MH, Kelleher M, et al: Resolution of cranial nerve paresis after endovascular management of cerebral aneurysms. Surg Neurol 68:500-504, 2007.

8 ) Mavilio N, Pisani R, Rivano C, et al: Recovery of third nerve palsy after endovascular packing of internal carotidposterior communicating artery aneurysms. Intervent Neuroradiol 6:203-209, 2000.

9 ) Stiebel-Kalish H, Maimon S, Amsalem J, et al: Evolution of oculomotor nerve paresis after endovascular coiling of posterior communicating artery aneurysms: a neuroophthalmological perspective. Neurosurgery 53:1268-1274, 2003.

10) Yanaka K, Matsumaru Y, Mashiko R, et al: Small unruptured cerebral aneurysms presenting with oculomotor nerve palsy. Neurosurgery 52:553-557, 2003.

\section{要 旨}

【目的】動眼神経麻痺で発症しコイル塞栓術を施行した硬膜内脳動脈瘤の動眼神経麻痺の術後回復経過について報告する. 【対象】動眼神経麻疩を伴って発症した硬膜内脳動脈瘤 6 例を対象とした。動眼神経麻痺の程度は完全麻疾が 4 例, 不全麻 痺が 2 例であった。くも膜下出血が4例，未破裂脳動脈瘤が 2 例であった。最大径 $5.8 \sim 8.7 \mathrm{~mm}$ で, 部位はIC-PC 4 例, ICAchor 1 例，BA-SCA 1 例であった.【結果】発症から 8 力月後の動眼神経麻疩の改善は，完全回復 4 例，不完全回復 2 例 であった，術前不全麻㿁の 2 例はいずれも完全回復した.【結語】コイル塞栓術後の動眼神経麻痺は改善する傾向がみられ， 動眼神経麻痺の症状を有することは，クリッピング術かコイル塞栓術かを決定する要因にはならない. 